\title{
Editorial
}

Journal of Innate

Immunity

\section{Myeloid Cells in Traffic}

\author{
Oliver Soehnlein ${ }^{a, b}$ \\ a Department of Pathology, Academic Medical Center, University of Amsterdam, Amsterdam, The Netherlands; \\ ${ }^{b}$ Institute for Cardiovascular Prevention, Ludwig-Maximilians University, Munich, Germany
}

Appearance of neutrophils and monocytes at the site of inflammation is a hallmark event during the inflammatory response. Trafficking of different leukocyte subsets requires a coordinated interaction of a variety of molecules in a process known as the leukocyte recruitment cascade. Classical descriptions of this multistep process consisted of leukocyte rolling, activation, adhesion and subsequent transmigration, involving selectins, cell adhesion molecules and chemokines as well as their respective receptors [1]. However, in recent years, this recruitment cascade has been refined by implementation of intermediate steps (e.g., adhesion strengthening and intraluminal crawling), discovery of tissue- (e.g., in liver, lungs and large arteries) and leukocyte-specific (e.g., for classical vs. nonclassical monocytes) recruitment mechanisms, as well as by recognition of intercellular interactions (e.g., between leukocyte subsets). This special issue accommodates all these new developments in several review articles.

Neutrophil homeostasis is maintained by a fine balance between granulopoiesis, retention in and release from the bone marrow as well as by clearance and destruction. Chemokine axes involving CXCR4 and CXCR2 are critically involved in the retention, mobilization and homing of neutrophils at sites of granulopoiesis [2, 3]. The importance of these axes in regulating myeloid cell homeostasis was shown under physiological conditions

\section{KARGER}

E-Mail karger@karger.com

www.karger.com/jin such as circadian changes [4] but also under inflammatory conditions where disturbance of these axes induces increases in circulating myeloid cells and worsening of inflammatory diseases $[5,6]$. The molecular mechanisms underlying the control of neutrophil homeostasis in steady-state and inflammatory conditions are reviewed in detail by Strydom and Rankin [7].

Neutrophils are the first leukocyte subset recruited to sites of inflammation. In the absence of microbial stimuli, i.e. in sterile inflammation, damage-associated molecular patterns (DAMPs) represent the trigger for neutrophil emigration. Important DAMPs are extracellular ATP $[8,9]$, mitochondrial formylated peptides $[10]$ and DNA [11], all of which are released by dying cells. Here, Pittman and Kubes [12] summarize mechanisms by which DAMPs set off the neutrophil recruitment cascade in sterile inflammation. Once activated and adherent to the endothelium, neutrophils need to breach the endothelial barrier to reach the inflammatory site. Intercellular junctions connecting individual endothelial cells form a tight barrier, thus making paracellular transmigration a highly regulated process. This process is complemented by emerging alternative routes of transmigration such as transcellular migration and reverse transmigration [13]. Here, Daniel and van Buul [14] summarize the molecular mechanisms that regulate endothelial cell-cell junctions and prevent or permit leukocyte transendothelial migra- (c) 2013 S. Karger AG, Basel

$1662-811 \mathrm{X} / 13 / 0054-0301 \$ 38.00 / 0$
Dr. Oliver Soehnlein

Institute for Cardiovascular Prevention Ludwig-Maximilians University Munich Pettenkoferstr. 9, DE-80336 Munich (Germany)

E-Mail oliver.soehnlein@gmail.com 
tion. Recent findings have illustrated that beyond the vascular lumen, the breaching of the venular wall can also involve an analogous cascade of adhesive events. For neutrophils, this involves a tightly regulated and sequential series of responses within venular walls, initiating with adhesive steps that guide neutrophils through endothelial cells lining the venular wall, followed by responses that mediate and regulate their migration through the pericyte sheath and the venular basement membrane [15]. The review by Voisin and Nourshargh [16] provides a detailed summary of the emerging adhesive cascade of neutrophils within venular walls, thus illustrating the complexities of neutrophil transmigration.

Based on the use of in vivo model systems, we have a good understanding of the basic principles of the classical recruitment cascade. While this commonly agreed paradigm might be applicable to most peripheral tissues, recruitment mechanisms may substantially vary in different organs, such as the lung $[17,18]$, liver $[19,20]$ and kidney $[21,22]$. These organs are highly specialized tissues with unique cell populations and structural organization, which enables them to fulfill their individual functions. The review of Rossaint and Zarbock [23] highlights current concepts of tissue-specific differences. The recruitment cascade receives another level of complexity when changing the focus towards chronic inflammatory processes such as atherosclerosis. There, it has been shown that neutrophils employ a different set of chemokine receptors to enter atherosclerotic lesions when compared to sites of microvascular inflammation [6]. This is based on the endothelial deposition of platelet-derived chemokines which attract neutrophils and monocytes alike $[5,6]$. In addition, neutrophils may pave the way for arterial infiltration of classical monocytes [24]. In this is- sue, Drechsler and Soehnlein [25] highlight the promiscuous pathways by which classical monocytes enter atherosclerotic lesions.

Once neutrophils, classical monocytes and macrophages have entered the site of injury or infection, they collaborate to remove foreign entities. After the inflammatory stimulus has been eliminated, the ongoing inflammatory response must be resolved to avoid excessive tissue damage and to initiate the return to tissue homeostasis in a process termed 'resolution' [26]. During the resolution of inflammation, a set of brakes prevents further infiltration of inflammatory cells and, interestingly, various mediators cooperate herein. Annexin A1, lipoxin A4 and resolvin D1, all of which act via the same receptor, namely FPR2, join forces to abrogate leukocyte recruitment, thus laying the ground for resolution of inflammation [27-29]. The review presented by Norling and Perretti [30] focuses on the mediators, targets and pathways orchestrating leukocyte trafficking during resolution. Neutrophil apoptosis is a crucial event during resolution of inflammation linking to reduced leukocyte recruitment and reprogramming of macrophages. In an original article, Christenson et al. [31] demonstrate the importance of autocrine interleukin- $1 \beta$ signaling of emigrated neutrophils in the regulation of their apoptosis.

Neutrophil and monocyte tissue infiltration are hallmark events during inflammation and offer various means of therapeutic interference. A detailed understanding of these processes in the various forms of inflammation (acute vs. chronic, sterile vs. microbial, macro- vs. microcirculation, different vascular beds) will allow for the tailoring of specific strategies to target the complex faces of inflammation.

\section{References}

1 Ley K, Laudanna C, Cybulsky MI, Nourshargh S: Getting to the site of inflammation: the leukocyte adhesion cascade updated. Nat Rev Immunol 2007;7:678-689.

-2 Martin C, Burdon PC, Bridger G, GutierrezRamos JC, Williams TJ, Rankin SM: Chemokines acting via CXCR2 and CXCR4 control the release of neutrophils from the bone marrow and their return following senescence. Immunity 2003;19:583-593.

-3 Eash KJ, Greenbaum AM, Gopalan PK, Link DC: CXCR2 and CXCR4 antagonistically regulate neutrophil trafficking from murine bone marrow. J Clin Invest 2010;120:24232431.
4 Scheiermann C, Kunisaki Y, Lucas D, Chow A, Jang JE, Zhang D, Hashimoto D, Merad M, Frenette PS: Adrenergic nerves govern circadian leukocyte recruitment to tissues. Immunity 2012;37:290-301.

5 Soehnlein O, Drechsler M, Döring Y, Lievens D, Hartwig H, Kemmerich K, Ortega-Gómez A, Mandl M, Vijayan S, Projahn D, Garlichs CD, Koenen RR, Hristov M, Lutgens E, Zernecke A, Weber C: Distinct functions of chemokine receptor axes in the atherogenic mobilization and recruitment of classical monocytes. EMBO Mol Med 2013;5:471-481.
6 Drechsler M, Megens RT, van Zandvoort M, Weber C, Soehnlein O: Hyperlipidemia-triggered neutrophilia promotes early atherosclerosis. Circulation 2010;122:1837-1845.

7 Strydom N, Rankin SM: Regulation of circulating neutrophil numbers under homeostasis and in disease. J Innate Immun 2013;5:304314.

8 Elliott MR, Chekeni FB, Trampont PC, Lazarowski ER, Kadl A, Walk SF, Park D, Woodson RI, Ostankovich M, Sharma P, Lysiak JJ, Harden TK, Leitinger N, Ravichandran KS: Nucleotides released by apoptotic cells act as a find-me signal to promote phagocytic clearance. Nature 2009;461:282-286. 
-9 Chen Y, Corriden R, Inoue Y, Yip L, Hashiguchi N, Zinkernagel A, Nizet V, Insel PA, Junger WG: ATP release guides neutrophil chemotaxis via $\mathrm{P} 2 \mathrm{Y} 2$ and $\mathrm{A} 3$ receptors. Science 2006;314:1792-1795.

10 McDonald B, Pittman K, Menezes GB, Hirota SA, Slaba I, Waterhouse CC, Beck PL, Muruve DA, Kubes P: Intravascular danger signals guide neutrophils to sites of sterile inflammation. Science 2010;330:362-366.

-11 Shimada K, Crother TR, Karlin J, Dagvadorj J, Chiba N, Chen S, Ramanujan VK, Wolf AJ, Vergnes L, Ojcius DM, Rentsendorj A, Vargas M, Guerrero C, Wang Y, Fitzgerald KA, Underhill DM, Town T, Arditi M: Oxidized mitochondrial DNA activates the NLRP3 inflammasome during apoptosis. Immunity 2012;36:401-414.

-12 Pittman K, Kubes P: DAMPs control neutrophil recruitment. J Innate Immun 2013;5: 315-323.

13 Woodfin A, Voisin MB, Beyrau M, Colom B, Caille D, Diapouli FM, Nash GB, Chavakis T, Albelda SM, Rainger GE, Meda P, Imhof BA, Nourshargh S: The junctional adhesion molecule JAM-C regulates polarized transendothelial migration of neutrophils in vivo. Nat Immunol 2011;12:761-769.

14 Daniel AE, van Buul JD: Endothelial junction regulation: a prerequisite for leukocytes crossing the vessel wall. J Innate Immun 2013; 5:324-335.

15 Proebstl D, Voisin MB, Woodfin A, Whiteford J, D'Acquisto F, Jones GE, Rowe D, Nourshargh S: Pericytes support neutrophil subendothelial cell crawling and breaching of venular walls in vivo. J Exp Med 2012;209: 1219-1234.
16 Voisin MB, Nourshargh S: Neutrophil transmigration: emergence of an adhesive cascade within venular walls. J Innate Immun 2013;5: 336-347.

$>17$ Zarbock A, Singbartl K, Ley K: Complete reversal of acid-induced acute lung injury by blocking of platelet-neutrophil aggregation. J Clin Invest 2006;116:3211-3219.

18 Grommes J, Alard JE, Drechsler M, Wantha S, Mörgelin M, Kuebler WM, Jacobs M, von Hundelshausen P, Markart P, Wygrecka M, Preissner KT, Hackeng TM, Koenen RR, Weber C, Soehnlein O: Disruption of platelet-derived chemokine heteromers prevents neutrophil extravasation in acute lung injury. Am J Respir Crit Care Med 2012;185:628-636

19 Wong J, Johnston B, Lee SS, Bullard DC, Smith CW, Beaudet AL, Kubes P: A minimal role for selectins in the recruitment of leukocytes into the inflamed liver microvasculature. J Clin Invest 1997;99:2782-2790.

20 McDonald B, McAvoy EF, Lam F, Gill V, de la Motte C, Savani RC, Kubes P: Interaction of CD44 and hyaluronan is the dominant mechanism for neutrophil sequestration in inflamed liver sinusoids. J Exp Med 2008;205: 915-927.

21 Block H, Herter JM, Rossaint J, Stadtmann A, Kliche S, Lowell CA, Zarbock A: Crucial role of SLP-76 and ADAP for neutrophil recruitment in mouse kidney ischemia-reperfusion injury. J Exp Med 2012;209:407-421.

22 Singbartl K, Forlow SB, Ley K: Platelet, but not endothelial, $\mathrm{P}$-selectin is critical for neutrophil-mediated acute postischemic renal failure. FASEB J 2001;15:2337-2344.

23 Rossaint J, Zarbock A: Tissue specific neutrophil recruitment into the lung, liver and kidney. J Innate Immun 2013;5:348-357.
24 Döring Y, Drechsler M, Wantha S, Kemmerich K, Lievens D, Vijayan S, Gallo RL, Weber C, Soehnlein O: Lack of neutrophil-derived CRAMP reduces atherosclerosis in mice. Circ Res 2012;110:1052-1056.

25 Drechsler M, Soehnlein O: The complexity of arterial classical monocyte recruitment. J Innate Immun 2013;5:358-366.

26 Ortega-Gómez A, Perretti M, Soehnlein O: Resolution of inflammation: an integrated view. EMBO Mol Med 358-366.

27 Perretti M, Croxtall JD, Wheller SK, Goulding NJ, Hannon R, Flower RJ: Mobilizing lipocortin 1 in adherent human leukocytes downregulates their transmigration. Nat Med 1996;2: 1259-1262.

28 Perretti M, Chiang N, La M, Fierro IM, Marullo S, Getting SJ, Solito E, Serhan CN: Endogenous lipid- and peptide-derived antiinflammatory pathways generated with glucocorticoid and aspirin treatment activate the lipoxin A4 receptor. Nat Med 2002;8:12961302.

29 Krishnamoorthy S, Recchiuti A, Chiang N, Yacoubian S, Lee CH, Yang R, Petasis NA, Serhan CN: Resolvin D1 binds human phagocytes with evidence for proresolving receptors. Proc Natl Acad Sci USA 2010;107:16601665.

30 Norling LV, Perretti M: Control of myeloid cell trafficking in resolution. J Innate Immun 2013;5:367-376

$>31$ Christenson K, Björkman L, Karlsson A, Bylund J: Regulation of neutrophil apoptosis differs after in vivo transmigration to skin chambers and synovial fluid - a role for inflammasome-dependent interleukin-1 $\beta$ release. J Innate Immun 2013;5:377-388. 